\title{
THE POSSIBILITIES OF ASIAN AMERICAN CITIZENSHIP: A CRITICAL RACE AND GENDER ANALYSIS
}

\author{
Clare Ching Jen \\ Denison University
}

\section{INTRODUCTION}

Conventionally, citizenship is understood as a legal category of membership in a national polity that ensures equal rights among its citizens. This conventional understanding, however, begs disruption when the histories and experiences of marginalized groups are brought to the fore. Equal citizenship in all its forms for marginalized populations has yet to be realized. For Asian Americans, rights presumably accorded to the legal status of citizenship have proven tenuous across different historical and political moments. Throughout U.S. history, "Asian American" or "Oriental" men and women have been designated aliens against whom white male and female citizenships have been legitimized. These categories of inclusion and exclusion- "citizen" and "alien"-are mutually constitutive; members are legitimate only when defined against the exclusion of "others." Citizenship must be conceptualized as a broader set of social and cultural memberships and exclusions beyond political rights and legal status. This article examines how scholarly works engage citizenship formations of "Asian American" women and men.

Othered as perpetual foreigners and "yellow perils," Asian Americans have faced immigration exclusion, detainment, deportation, enforced quarantine, segregation, internment, bars to citizenship, and systemized denaturalization. Americans of Asian descent have been in the United States for over 150 years; yet, they are still culturally stereotyped as foreign and un-American in media and other forms of representation. As early as 1794, Chinese started settling in Hawaii (Okihiro $2001,9)$. In the 1850s, Chinese contract labors migrated to Hawaii to work on sugar plantations; at the same time, 20,000 Chinese arrived in California to seek their fortunes in the Gold Rush (ibid 13). Unregulated immigration ended when the Page Act of 1875 effectively halted immigration of "Mongolian" women based upon stereotypes of deviant sexuality (ibid 141). Anti-Chinese sentiment culminated with the Chinese Exclusion Act (1882) which barred entry of the Chinese male laboring class, followed by immigration bars on Japanese (1907), Koreans (1907), Asian Indians (1917), and Filipinos (1932) (ibid 19, 35). The national 
origins quota system was not eliminated until the Immigration and Nationality Act of 1965 (Ngai 2003, 3). Historically, the U.S. has barred or restricted the immigration of unwanted groups based on designations of race, national origin, gender, sexuality, and class.

The history of citizenship legislation is equally racialized, gendered, and classed. The Naturalization Act of 1790 granted the right to U.S. citizenship only to "free white persons," excluding indentured servants, slaves, and most women (Volpp 2001, 58; Asian Women United of California 1989; 423; U.S. Citizenship and Immigration Services 2004). From 1894 to 1952, Japanese were declared ineligible for naturalization (Okihiro 181). Birthright citizenship for Chinese Americans was finally recognized in the Wong Kim Ark (1898) decision, even though ten years earlier the Fourteenth Amendment (1888) classified citizens as:

All persons born or naturalized in the United States and subject to the jurisdiction thereof, are citizens of the United States and of the State wherein they reside. No State shall make or enforce any law which shall abridge the privileges or immunities of citizens of the United States; nor shall any State deprive any person of life, liberty, or property, without due process of law; nor deny to any person within its jurisdiction the equal protection of the laws. (U.S. House of Representatives 2004)

This Amendment, however, did not protect women, especially U.S.-born women of Asian descent, from dependent citizenship. In 1907, dependent citizenship extended to include women with U.S. citizenship who were married to non-citizen men, such that these women lost their legal citizenship status (Volpp 59). The Cable Act in 1922 primarily affected women who married Asian men, as it stripped legal status from U.S. citizen women married to men ineligible to naturalize (Bredbenner, quoted in Volpp 59). These women, if racialized as Asian, were then ineligible for naturalization based upon the Naturalization Act of 1790 .

Instances throughout history have exemplified the tenuousness of citizenship rights when racially embodied. For instance, the mass internment of Japanese Americans in U.S. concentration camps during World War II is perhaps the most written about subject in Asian American history (Okihiro 100). From 1942-1946, over 120,000 Japanese Americans, of whom two-thirds were legal citizens, were removed from their homes and properties and detained in camps. By labeling this group "enemy aliens," the U.S. government essentially revoked the rights of citizenship for Japanese Americans upon fabricated evidence that they posed risks to national security (ibid 100-127). This history disrupts the assumption that legal citizenship ensures equal rights. If citizenship as legal status can be rendered meaningless, then of what value is this categorization? What 
then inscribes individuals as Asian "Americans" as opposed to Asian aliens? In other words, what demarcates Asian Americans as "citizens"? Are there forms of citizenship, other than legal status, that can explain the experiences and histories of Asian American men and women, as well as provide anti-racist, feminist tools of resistance in the struggle for equality?

This critical race and gender analysis explores conceptual models of U.S. citizenship in the context of intersecting dimensions of difference and presents citizenship as sets of social and cultural memberships and exclusions beyond just political rights and legal status. More broadly conceptualized, citizenship serves as a useful tool for analyzing processes of inclusion and exclusion, as well as sites of oppression and possible resistance. This analysis examines formations of "Asian American" women and men through various citizenship discourses. For the purposes of this essay, "Asian American" denotes Asian-raced, gendered, sexualized, and classed persons located within U.S. geopolitical boundaries, in circulation in the nation's cultural imagination, and/or otherwise engaged with migration policies to cross U.S. borders. This definition purposefully casts a wide net of inclusion in recognition of the inconsistencies and incoherencies involved in attempting to operationalize a population as if static through time and across situations. Finally, this analysis examines the varying theoretical and methodological approaches taken by scholars who use citizenship or seek to define citizenship as it pertains to the experiences of Asian American women and men.

The scope of this analysis is limited in the format of material examined. It primarily includes monographs, journal articles, book chapters, and essays in edited anthologies. Non-print materials, as well as government documents, are excluded. It is expansive in its disciplinary scope. It draws from scholarship in the following areas: Asian American studies; women's studies; history; public anthropology; citizenship studies; communication studies; literary studies; education; legal studies; and immigration history.

This essay organizes scholarship on Asian Americans and citizenship around analyses of racialized and gendered citizenships. Two particular scholarly works provide the framework for this paper's organization and analyses. First, Leti Volpp demonstrates the limitations of four predominant citizenship discourses-legal status, rights, political activity, and identity - through a lens of Asian American racialization (2001). Texts that discuss citizenship and Asian Americans touch upon one or more of these categories. Analyses through both racialized and gendered lenses suggest the interrelatedness of these four meanings of citizenship. For example, citizenship as the struggle for identity for marginalized groups without legal status and accompanying rights may entail political 
activity as a form of resistance. Laura Kang (2002) extends Volpp's critique by conducting a more in-depth analysis of how race and gender intersect in systems of citizenship. She provides an exemplary critique of racialized and gendered citizenship-making processes that leads to her theorization of "Asian American women" as an incoherent construction. Kang's work is significant as most scholarship on citizenship and Asian Americans operate according to assumptions of a universal male referent that often leaves uncritiqued processes of gender and racial formations. ${ }^{1}$ The theoretical and conceptual tools offered by Volpp and Kang are used to analyze and organize how different scholarly works approach meanings of citizenship for Asian American women and men.

The following themes emerge. First, a category of scholarship emerges that does not complicate meanings of citizenship beyond legal status or the universal male referent. These texts utilize U.S. citizenship for Asian Americans (presumably men) as indices or measures in their studies with the assumption that citizenship rests solely in the legal domain. Second, examinations using Asian American history confront the assumption that citizenship as legal status and rights equates equality but do not forgo legal status as part of the struggle toward equality. Operating within legal studies and immigration histories, these critiques historically examine the events of World War II and the Cold War. These analyses also primarily use race as a critical lens and make little mention of gender. Third, a number of works focus on culture as a space of identity formation and political activity as related to processes of citizenshipmaking. This third category of scholarship includes inquiries that center women and/or gender its subjects. It is through many of these scholars' readings of culture through lenses of race, gender, and labor that connections become most apparent between Volpp's four citizenship discourses. These scholars engage cultural productions that range from the following sources: Asian American and Black feminist literatures; Asian American women's autobiographical narratives and testimonials; the Black press; and ethnographic studies of culture as everyday acts and practices. This third category of scholarship is divided over the role such cultural productions play in achieving a more inclusive idea and reality of equal citizenship, and the texts that do engage women or gender vary in their level of analyses. Additionally, works that view women as formed through racialized and gendered processes are of ten situated within a transnational context. Finally, a line of scholarship engages language as a domain of citizenship and national identity formations with racialized, but not explicitly gendered, implications. These works are particularly

1 I use Michael Omi and Howard Winant's concept of "racial formation." They define racial formation as "the sociohistorical process by which racial categories are created, inhabited, transformed, and destroyed" $(1994,55)$. 
interested in the role linguistic capital plays in shaping the ideal American citizenry within the institution of education. These four patterns emerge from a critical assessment of existing scholarship; however, they are by no means mutually exclusive, rather they are interdependent and can overlap at times.

\section{RACIALIZED AND GENDERED CITIZENSHIP DISCOURSES}

The construction of Asian American women and men as (il)legitimate members of the national body can be analyzed through racialized and gendered critiques of various citizenship discourses. In " 'Obnoxious To Their Very Nature': Asian Americans and Constitutional Citizenship," Volpp engages four distinct discourses of citizenship and demonstrates their limitations through the critical lens of Asian American racialization with only cursory attention to gender (2001). Alternately, Kang (2002) in "Historical Reconfigurations: Delineating Asian Women as/not American Citizens" primarily focuses on Volpp's first two discourses-legal status and rights - and conducts an analysis of citizenship discourses as both raced and gendered through a theorization of "Asian American women." When synthesized together, these texts are significant as they trace different, yet interconnected, discourses and demonstrate citizenship as an analytical tool that results in an antiessentialist theorization of "Asian American women."

Volpp's analysis is based upon four categories: legal status, rights, political activity, and identity (58). Citizenship as legal status designates individuals as legal citizens according to U.S. Constitution or statute. Citizenship as rights is based upon a liberal notion of rights and presumes civil, political, and social rights of citizens as necessary to achieving equal membership in society. These first two discourses frame the citizen as a passive object that is granted rights. The third distinct discourse positions citizenship as political activity in the community. Finally, citizenship as identity refers to people's collective experiences. These third and fourth discourses assume the citizen to be an active subject with subjectivity (ibid). The author juxtaposes the racialization of Asian Americans with these four discourses. She contends that while it may be more acceptable in the present day to consider Asian Americans as legitimate recipients of formal rights - that is, the first two discourses-it is less acceptable to consider Asian Americans as subjects politically engaged in and able to represent the identity of the American nation (ibid). In other words, even though some Asian Americans may have obtained the documented legal status of "U.S. citizen," they are still not fully considered citizens in terms of politics and American national identity. These latter two discourses are further elaborated upon in the categories of scholarship addressing culture and language education. 
Volpp reveals the insufficiency of the first discourse by providing an historical overview of how citizenship as legal status has racially excluded Asian Americans. The U.S. Constitution from its outset provided no racial guidelines for citizenship; however, the 1790 Naturalization Law limited naturalization to "free white" "aliens and, after the U.S. Civil War, was amended to include " "aliens of African nativity or African descent'" (58). The author discusses the Fourteenth Amendment as a rejection of Judge Taney's opinion in Dred Scott v. Sandford (1857) that allowed Blacks citizenship through birth and naturalization. The Fourteenth Amendment, however, still excluded Asians due to naturalization restrictions. She connects this inability of Asian immigrants to naturalize to the maintenance of alien land laws prohibiting Asian immigrants from owning land. According to the author: "The racially defined inability to own property, to naturalize, and to immigrate, created a triple burden that constituted, in opposition to the citizen, the 'alien': one unable to engage in the basic functions of the citizen, and therefore politically powerless" (59). Volpp's historical overview of restrictions to citizenship as legal status continues with the Supreme Court decision in Wong Kim Ark (1898) that found the Fourteenth Amendment to apply to Chinese born in the United States. However, she states, "It is doubtful that Wong Kim Ark represented any significant shift in the acceptance of the Chinese as citizens" (60). In other words, legitimate birthright citizenship did not lead to the incorporation of Chinese Americans into the national body. Brooke Thomas, as discussed later in this literature review, recuperates some productive value in the Wong Kim Ark decision in the struggle of Asian Americans to attain equal citizenship (1998).

Both Volpp and Kang examine the intersection of gender and race in naturalization guidelines; however, Kang focuses specifically on how these federal statutes constitute part of a "genealogy" that constructs certain subjects as "Asian American women" through varied processes of exclusion. Kang structures her argument by reviewing citizenship and naturalization measures throughout U.S. legal and political history, and her analysis of race and citizenship laws cites many of the same legislations as Volpp's piece. In Kang's analysis of racialized and gendered citizenship, she similarly highlights the 1922 Cable Act and its 1930 amendment; however, she delves more extensively than Volpp does into how this legislation created a "clearly racialized division among American women" and "denaturalized" the U.S. born Chinese woman from American citizenry (140). Through the course of trying to "(re)narrate Asian American women as an integral definitional other to a normative, legal 'American' citizenship," she became aware of the construction of this category. This genealogy of Asian American women consists of: 
modes of exclusion, detention, segregation, deportation, and denaturalization of the Asian female from the U.S. citizenry [that] bring[s] 'Asian American women' into critical relief not as a descendant grouping of single origin but rather as a tenuous identification situationally congealed and then too internally differentiated-according to nationality, class, sexuality-through a disconnected, even haphazard jumble of cultural constructions, local and federal legislations, and enforcement mechanisms. (Kang 141-2; emphasis in original)

Kang highlights "Asian American women" as objects of study that are not already formed entities; they are "situationally congealed" through complicated webs of representations, regulations, and enforcements that include processes of citizenship.

Volpp exposes the contradictions in liberal notions of citizenship, such as citizenship as a provision for equal rights - the second citizenship discourse. Liberalism frames its subjects as abstract citizens in which citizens have equal claims to equal rights (61). This, however, proves fictitious for racialized subjects, as the U.S. government has historically failed and continues to fail to protect their civil, political, and social rights. According to the author: "Liberal notions of citizenship suppress particular and local differences, separating one's abstract will from the specifics of social conditions, such as the racialized body" (ibid). It supports abstract notions of colorblindness, that rights written into law actually equate substantive rights, without regard to actual historical and structural inequalities. With Kang's argument in mind, citizenship is a liberal myth for subjects racialized and gendered as Asian American women. Liberalism is insufficient for understanding the contradictory location of Asian Americans: "While there is no question that American law mandates that Asian Americans be afforded the rights of all citizenry under abstract principles of egalitarian plurality, their racial location still functions to disrupt the enjoyment of full political and social equality" (Volpp 62). Again, the racial and gender location of Asian American women functions to prevent their enjoyment of equality.

With regard to her third discourse, Volpp proposes how Asian Americans have historically been prevented from participating fully in citizenship as political activity. She shows how Asian Americans have been restricted based upon race from owning property-a right considered instrumental to civic republicanism. Chinese immigrants were characterized as incapable of practicing democratic principles around the late nineteenth century; Japanese Americans were seen as disloyal during World War II; Chinese Americans in the present-day are seen as unscrupulous campaign financiers and government spies. 
Finally, the author reviews the fourth discourse-citizenship as membership to a national identity — and shows how stereotypes of Asian Americans have precluded such belongings. She cites a contemporary example of popular news media's othering of Asian American public figures as non-American and foreign, including stereotypes of "yellow peril" and "model minority"-both of which continue to operate on assumptions that Asian Americans are incapable of democratic practice. Volpp goes as far as to say: "In fact, 'citizen' and 'Asian' could be said to function as antonyms in the United States context" (66). Identity is posed as particularly salient in citizenship-making processes for Asian American women and men. Most of the scholarly works in this review that analyze aspects of national identity examine cultural productions and language.

This critical race and gender analysis is concerned with how Asian American women and men are produced through citizenship-making processes. Volpp's essay operates through a critical race-though largely genderless-lens, while Kang theorizes citizenship as racialized and gendered through the "genealogy of "Asian American women" " Kang 132). Volpp concludes:

There is a danger to try to define citizenship in isolation from identity, since particularities will determine how successfully such citizenship can be accessed and enjoyed. It is imperative to address all four citizenship discourses if one is truly in search of the guarantee of constitutional citizenship, for only with access to all four forms of citizenship can one be deemed a full citizen.

The four forms of citizenship must be achieved in order for Asian Americans to enjoy the guarantees of full constitutional citizenship. The following sections examine existing scholarship on citizenship and Asian Americans as racialized and gendered discourses that address one or a combination of the following forms of citizenship: legal status, rights, political activity, and identity.

\section{ASIAN AMERICAN “CITIZENSHIP” AS INDICES}

One pattern in the literature assumes citizenship as solely Volpp's first discourse-legal status-and utilizes U.S. citizenship in relation to Asian Americans as study indices or measurements. This pattern is divided into two categories: 1) citizenship as legal status is used to characterize individuals as, and to measure traits defining, Asian American, and 2) court rulings deciding citizenship are used to indicate legitimization 
processes. Both these categories of scholarship assume or specifically refer to men with little critical analyses of gender.

\section{Asian + U.S. Citizenship = Asian American $?$}

Virginia Mansfield-Richardson's Asian Americans and the Mass Media attempts to operationalize "Asian American" in the first content analysis of mainstream media coverage of Asian Americans (2000). She analyzes how 20 of the largest U.S. newspapers cover Asian Americans and issues pertinent to Asian American communities during 1994-1995. She also surveys more than 50 Asian American journalists about their perceptions of media coverage as relevant to Asian Americans and their ethnic communities. In outlining the scope and depth of her study, she defines her use of "Asian Americans." She consults a number of Asian American organizations and finds that most allow members to self-identify, although several of the organizations do not include Middle Eastern Americans. She also details how the Asian Americans Information Directory (1992) and U.S. Census differently classify ethnic subgroups. The author contends that no organization or government agency provides a single stable, unalterable definition of "Asian American."

She provides the following points in her study's classification schema that includes both ethnicity and citizenship in defining an Asian American:

1) Having an ethnic heritage with direct descent from any of the Asian American ethnic sub-groups listed in the 1990 U.S. Census or the 1992 Asian American Information Directory, and having United States citizenship. For example, a person whose ethnic lineage consists of only relatives of Japanese descent. This includes persons who are of full Asian ancestry and who are adopted by U.S. citizens of any race.

2) Having an ethnic heritage with direct descent from any two or more of the Asian American ethnic subgroups, and having United States citizenship. For example, if a person's father is of Chinese descent and his or her mother is of Filipino descent.

3) Having an ethnic heritage with any one relative being of an Asian American ethnic sub-group as far back as three generations, and having United States citizenship. For example, this would include a person whose great-grand-father was Indonesian, but all other relatives since were Caucasian. Any person with a combination of mixed races with an Asian American 
ethnic sub-group going back three generations would be included in this category.

4) Immigrants (which include refugees) with Asian or Pacific Islander heritage, or heritage that is included under numbers one, two or three of these definitions, who are living in the United States. (16)

The first three categories demand that individuals possess a certain legal status, that of U.S. citizenship, to be considered Asian American. The fourth category, however, does not rely upon this legal designation.

The author explains the fourth classification, as it seems contradictory to consider an Asian immigrant without U.S. citizenship an Asian American. The fourth category is as follows:
Asian, Southeast Asian, Near Asian or Pacific Islander who has been living in the United States for several years (sometimes most of his or her life), but who has not changed his or her citizenship to that of a U.S. citi- zen, is very Americanized and has many of the same at- titudes, personal identifications and experiences of prejudice as a person born in the United States of parents who are Asian, or some racial mix thereof which in- cludes Asian heritage. (17)

This explication supplants legal status as the marker for being "American" and hinges the fourth criterion upon what it means to be an "Americanized" Asian-as having the "attitudes, personal identifications and experiences of prejudice" of U.S. citizens with an Asian heritage. This Americanization is an interesting substitution for the legal status of U.S. citizen as a criterion for being Asian American. Is this then how Asian Americans can be defined-by being "Americanized" and having certain "attitudes," "identifications" and "experiences of prejudice?" She explains further, however, that of ten the only criterion that matters is if a "person is perceived as being Asian by other people within a community which results in some form of insult or prejudice, whether intentional or not, against that person" (17). In other words, being externally labeled as "Asian" trumps the author's complicated elaborations and prior criterion that prioritize an internal cultural development and identification or legal status. Is this then what it means to be Asian American-an external calling out as Asian that results in insult and prejudice? The author's attempt to operationalize the definition of Asian American reflects the insufficiencies of citizenship, in its legal sense, as a measure of "Asian American."

Philip Q. Yang's “Sojourners or Settlers: Post-1965 Chinese Immigrants" also relies on U.S. citizenship as a legal designation to define 
who and what is Asian American (1999). The author explores indices and measures for determining the settlement orientations of post-1965 immigrants from China. Numerical data, as well as historical records and memoirs, support the sojourner hypothesis for the majority of Chinese entering the U.S. before the passage of the 1882 Chinese Exclusion Act. This hypothesis conceptualizes Chinese immigrants as sojourners, meaning they arrive in America with the intention to return to China after accumulating savings. However, he seeks to disprove this hypothesis for post-1965 Chinese immigrants. It is assumed these immigrants are permanent settlers even though very little empirical evidence exists (63). The author seeks indices and measurements related to settlement orientations. The significance of this is that the legal notion of citizenship is used to disrupt the binary of "sojourner" and "settler" and, by implication, the constructed binary of Asian American and Asian alien. He also hypothesizes that the settler orientation is more likely for female Chinese immigrants as opposed to their male counterparts. He bases this hypothesis upon the belief that women reap greater benefits from settlement, such as "job opportunities, personal freedom, and more equal status for women than for men" (67).

Yang ultimately demonstrates that post-1965 Chinese immigrants are not "sojourners" but permanent settlers; he refutes the "perpetual foreigner" stereotype that negatively affects the status and political representation of Chinese Americans and, in general, Asian Americans. On the other hand, the now empirically supported perception of post-1965 Chinese immigrants as "settlers" shapes this group as ". . . an integral part of American society. They are here to stay, to relish the opportunities offered by their adopted country, and to contribute to the building of an even better America" (86). Yang never seeks to disrupt the legitimacy of the sojourner versus settler binary. Though the author attempts to incorporate gender and socioeconomic status into his analyses, he utilizes these dimensions of identity and difference as little more than variables that determine settlement decisions. In addition, he makes no mention of transnational migrants, perhaps because to do so would disrupt the sojourner-settler binary. He utilizes citizenship as legal status and, in turn, a measure of settlement orientation within a limited framework. Even by empirically demonstrating that the majority of post-1965 Chinese immigrants are oriented towards settlement, this study does little more than refute a stereotype by replacing it with its uncomplicated foil. It is this dualism that needs disruption and complicating. While Mansfield-Richardson's attempt to operationalize "Asian American" results in contradictions and discrepancies that are due less to a flaw in her research design than to the reality of its actual complication, Yang's usage of "acquisition of citizenship" as an indicator of national identity is limited in its 
research question and design and, consequently, strays from Asian Americanist intents to disrupt dualisms and hierarchies.

\section{ASIAN AMERICAN “CITIZENSHIP” AS LEGITIMIZING WHITE DOMINANCE}

In scholarly research that uses legal citizenship as indices or measurements, citizenship is used as an indicator of legitimization processes. One such example is Susan Olzak and Suzanne Shanahan's "Racial Policy and Racial Conflict in the Urban United States, 1869-1924" (2003). This study considers court rulings that deny U.S. citizenship to Asian Americans as legitimizing white dominance in America that consequently lead to increased rates of violence against Asian Americans. By tracking data on racial conflict events during this time period, the study finds support for its hypothesis: "Laws and rulings legitimating white dominance over nonwhites increase the rate of violence against Asian and African American minorities" (486). They ultimately explain that court rulings on citizenship that reinforced racial boundaries increased the rate of racial conflict events involving white Americans and Asian minorities. Citizenship is used as a historical indicator for legitimization processes that operated in political and legal realms and that maintained racial barriers and white dominance over Asian minorities.

In "Race, Nation, and Citizenship: Asian Indians and the Idea of Whiteness in the U.S. Press, 1906-1923," Hemant Shah employs the conventional legal notion of citizenship (1999). The racialized de-legitimization of Asian Indians as possible U.S. citizens is framed as the endgame in the U.S. press' agenda to racialize Asian Indians as non-white. The author conducts a textual analysis of printed press news coverage of Asian Indians from a central California daily newspaper and a national prominent newspaper from 1906-the year Asian Indians first applied for citizenship - to 1923-when Asian Indians were declared ineligible for naturalization by the U.S. Supreme Court (1999). He extracts five major themes found in the analysis of 156 stories on Asian Indians. The second most common theme, "Immigration and naturalization," is relevant. Shah notes that coverage of the 1923 Supreme Court case, that revoked Bhagat Singh Thind's U.S. legal citizenship based on his not being "White," actually sidestepped the "racial logic of exclusion" (260). The press reported rationale other than racial exclusion. This was the press' means of sidestepping issues of American racism and scapegoating Asian Indians as supposedly unwilling to assimilate. The guise of America as founded upon equality and fairness was maintained by the press' skewed coverage. In Shanahan and Olzak's and Shah's research, citizenship is used in its conventional legal sense as an indicator of insti- 
tutional processes, such as the press and court rulings, that legitimized racialized membership in a nation-state.

\section{MYTH OF CITIZENSHIP AS LEGAL STATUS AND RIGHTS}

Volpp's and Kang's critique of citizenship discourses explodes assumptions of abstract citizenship. Synthesized together, they demonstrate how citizenship as legal status and rights has been differentially applied to subjects through different moments in time and through processes of racialized and gendered exclusions. The scholarly works examined in this section also confront color-blind assumptions of abstract, liberal citizenship through a racialized, though not gendered, lens. In addition, one particular text challenges the assumed meaningless of citizenship as legal status in the struggle towards equality.

In conversation with Volpp's four citizenship discourses, Eric Yamamoto, Margaret Chon, Carol Izumi, Jerry Kang, and Frank Wu, in Race, Rights and Reparation: Law and the Japanese Internment, impressively dispel the notion of citizenship-as legal status and rights-as uncomplicated by race (2001). However, they pay little attention to gendered processes of citizenship. In addition, they touch upon political activity as it documents the Asian American community's fight for reparations from the U.S. government. Citizenship as identity is touched upon; however, it is not theorized in ways similar to other scholarly works, specifically those that examine Asian American cultural production.

Yamamoto et al contend that the internment of 120,000 Japanese American citizens and legal permanent residents during World War II resulted from legalized racial discrimination and not from viable national security fears. They demonstrate how race was central to the government's decision during World War II to restrict the civil liberties of this marginalized group (15). Moreover, they show how legal processes construct Asian Americans as particularly raced and othered. The term "historical race" refers to the historical experiences of Asian Americans as outsiders, in contrast to white Americans who are assumed to "belong" legitimately in the United States (13). Furthermore, the racialization of Asian Americans nullifies notions of an abstract citizenship accorded through legal status. The authors demonstrate that the formal legal status of Japanese Americans as American citizens was rendered meaningless through supposedly legitimate legal and political processes.

This dis-identification with national identity is a theme throughout most of these reviewed texts, including Mae M. Ngai's Impossible Subjects: Illegal Aliens and The Making of Modern America (2004). This text is a historical study of race and U.S immigration policy and practices during 1924 to 1965 . Her research fills a knowledge gap in immigration 
historiography. Most immigration scholarship focuses on the periods pre1924 and post-1965; however, the author deems 1924-1965 significant as it marks the start and end of the national origins quota system. Established by the Johnson-Reed Immigration Act (1924), the quota system set forth a "new ethnic and racial map based on new categories and hierarchies of difference" and "articulated a new sense of territoriality, which was marked by unprecedented awareness and state surveillance of the nation's contiguous land borders" (3). Not much scholarship addresses how this system of immigration restriction and, by implication, restrictions on naturalization and citizenship, actually functioned (3).

As Yamamoto et al discuss "historical race," Ngai suggests the concept of " 'alien citizens'-persons who are American citizens by virtue of their birth in the United States but who are presumed to be foreign by the mainstream of American culture and, at times, by the state" (2). Ngai looks at the "alien citizenship" of Japanese Americans and Chinese Americans during World War II and the Cold War and focuses on the Denationalization Act (1944) that enabled a citizen to voluntarily renounce citizenship. This act resulted in 5,000 citizenship renunciations by Japanese Americans. Scholarship on internment and renunciation treats its subjects as necessarily coerced or in a state of mental instability to renounce citizenship. This, according to Ngai, is the result of other scholars projecting their own valorizations of formal citizenship onto the renunciants (198). Instead, she suggests other explanations: 1) dual nationalisms that may be 2) equally weak loyalties to the U.S. and Japan and/or 3) the result of pragmatic decisions to avoid resettlement out of the concentration camps during the war and the white American hatred outside the camps (200). This suggests an acknowledgement of the myth of citizenship as legal status and rights. A renunciation of a legal status that apparently holds no value is not much of a loss, especially when faced with an uncertain future.

The notion of citizenship as only legal status must be disrupted; however, it must not be foregone as part of the struggle towards equality. Brooke Thomas, in her article "China Men, United States v. Wong Kim Ark, brings together legal and literary analyses to offer a slightly different rendition of how the Supreme Court's decision in Wong Kim Ark (1898) was productive for Asian Americans. While Volpp sees Wong Kim Ark as a limited victory for Asian American citizenship in the legal sense, Thomas sees the decision as significant in vision-it rejects racial exclusions to birthright citizenship and privileges Chinese Americans as citizened subjects. Through an analysis of Wong Kim Ark and Louis Althusser's concept of "subject," she puts forth citizenship as a lens through which subjectivities can be expanded. She discusses Maxine Hong Kingston's model of citizenship from China Men-that belonging 
to America involves the reconstruction of multiple subjectivities and identities territorially bound within the United States. This is important with respect to Wong Kim Ark as birthright citizenship accorded to Chinese Americans allowed for dual citizenship. Though the author concedes the Wong Kim Ark decision does not articulate a universally inclusive citizenship, she still holds birthright citizenship as significant. If citizenship is to be viewed as a lens for understanding multiple subjectivities and identities that interact within territorially-defined spaces, then the acquisition of legal citizenship as a result of the Wong Kim Ark decision is meaningful.

\section{ASIAN AMERICAN CITIZENSHIP AND CULTURE}

Scholarly works that examine culture for meanings of citizenship for Asian American men and women mostly address Volpp's third and fourth form of citizenship-political activity and identity. Examples of cultural productions span literatures, autobiographical narratives, testimonials, cultural events, and everyday acts and practices. These literatures conflict over the usefulness of cultural productions and representations in achieving, what Volpp would term, the "guarantees of Constitutional citizenship" for Asian American men and women. Many of these works use citizenship and culture to center Asian American women and men, or to examine processes of racial and gender formations, in their analyses. The following texts are divided into two sections: 1) works that consider culture as a promising site of resistance and 2) those that consider culture debilitating. For those texts that uphold culture's potential, there is a subset of scholarship that foregrounds culture as everyday acts and practices within a transnational context.

\section{“CULTURAL CITIZENSHIP” AS PRODUCTIVE SITE OF RESISTANCE}

Lisa Lowe's seminal text, Immigrant Acts, presents Asian American culture as a site for an embodiment of an alternative citizenship (1996). In conversation with Volpp's four forms of citizenship, Lowe specifically expands upon discourses of political activity and identity. She dispels the liberal assumption of abstract, color-blind citizenship as inclusive of Asian American men and women by providing a history of immigration exclusion acts from the mid-nineteenth century to the increasing transnational gendered labor of the present day. She elaborates on the significance of culture in forming the citizen:

Citizens inhabit the political space of the nation, a space that is, at once, juridically legislated, territorially situated, and culturally embodied. Although the law is perhaps the discourse that most literally governs citizenship, 


\begin{abstract}
U.S. national culture-the collectively forged images, histories, and narratives that place, displace, and replace individuals in relation to the national polity-powerfully shapes who the citizenry is, where they dwell, what they remember, and what they forget. (2)
\end{abstract}

She argues that American national culture forms subjects into citizens and that the mainstream national narrative does not account for the histories and experiences of Asian Americans and transnational Asian immigrant women workers. She contends that marginalized groups, those barred from national culture, produce alternative cultural sites to negotiate their own sense of national identities and to effect social change.

Examples of alternative cultural sites include the individual and collective narratives or testimonials of Asian immigrant women workers. She analyzes testimonials delivered by Asian immigrant women workers at a community hearing in Oakland, California (154). This hearing was sponsored by Asian Immigrant Women Advocates (AIWA)-a labor organizing group that works with Asian immigrant women garment workers around issues of labor rights and that strives to connect Asian American and Asian immigrant women around issues outside of the workplace, such as healthcare and literacy (154-6). She approaches these testimonies as alternative cultural mediums in which women display "narrative progression[s]" from individual subjectivities to collective subjectivities and political action (155). Viewing these testimonies by Asian immigrant women as legitimate knowledge challenges traditional Western epistemology (158). Analyses of such forms of culture are vital to understandings of how marginalized populations negotiate their own meanings of citizenship. She frames her reading of testimonials within a discussion of the " 'racialized feminization of labor' in the global restructuring of capitalism" (ibid). The women with whom AIWA work are examples of female laborers who migrate to the U.S. from countries that were once colonized by the U.S. or that are currently neocolonized by U.S. capitalism (165). Placed within conversations of citizenship, Lowe contends that:

The Asian immigrant and Asian 'American' women, like other racialized women, have a different political formation than that prescribed by either narratives of liberal capitalist development and citizenship or the narratives proposed by. . oppositional movements of the 1970s. The isolation of one axis of power, such as the exploitation of labor under capitalism, masks the historical processes through which capitalism has emerged in conjunction with, and been made more efficient by, other systems of discrimination and subordination-patri- 
archy, racism, and colonialism. The Asian 'American' woman and the racialized woman are materially in excess of the subject 'woman' posited by feminist discourse, or the 'proletariat' described by Marxism, or the 'racial or ethnic' subject projected by civil rights and ethno-nationalist movements. (141-2; emphasis in original)

Her critique of Asian American citizenship-a privileging of cultural production as offering possibilities and potentialities for political activity-actually advocates intersectional and transnational approaches to the study of how Asian American women and Asian immigrant women negotiate the contradictions of citizenship, especially within the context of transnational capitalism. That "Asian American women" are considered "materially in excess" of the following scholarly and political discourses-feminist, Marxist, and ethno-nationalist-resonates with Kang's genealogy of "Asian American women." It can be said that Kang, too, finds "Asian American women" in "excess" of the traditional trappings of an identity group, as "not a descendant grouping of single origin but rather as a tenuous identification situationally congealed and then too internally differentiated" (141-2). In other words, Kang and Lowe agree that ethno-nationalist identity politics do not precisely account for the existences of Asian American women throughout history. This is where Lowe offers culture as a productive site of citizenship-making.

While Lowe approaches the testimonials of present day Asian immigrant women workers as part of racial and gender formation processes, Helena Grice only centers the autobiographical narratives and literature of Asian American women (2002). Her chapter "Citizenship and National Identity: Cultural Forms and Formations" engages Volpp's fourth discourse of citizenship-identity. Its focus is a comparative analysis of externally imposed national identities as set against the condition of citizenship in the narratives of Japanese American and Chinese American women writers. The author, however, fails to make a strong case for why she focuses on women's writing, as she barely analyzes how these cultural productions are expressions of these women's specific standpoints situated by intersecting systems of racism and sexism.

Grice finds in Maxine Hong Kingston's China Men (1981) a formation of the American frontier as masculinized space situated between nation and non-nation where those excluded from national membership are marginalized. This echoes Volpp's discourse of citizenship as identity but with an additional analysis of race, masculinity, and space. The main strength of this author's text is her centering of Asian American women's writing placed in conversation with the identity discourse of citizenship. As Volpp reveals the restrictions placed on Asian American 
membership to the national identity, Grice shows how Asian American women writers through cultural productions negotiate these externally imposed national identities of marginality that, consequently, preclude full equal citizenship for Asian Americans. While she does not claim to conduct gendered analyses, her focus on Asian American women with only slight attention to gendered processes is questionable. If the author had conducted a gendered analysis of Asian American women's writing that negotiates citizenship, the reader would engage citizenship processes as racialized and gendered and not as amorphous, ill-defined processes that somehow impact certain subjects that happen to be of a certain race and gender.

Both Lowe and Grice address Volpp's third and fourth form of citizenship-political activity and identity-and examine the cultural productions of Asian American women as promising alternative sites of resistance. They differ, however, in that Lowe critically examines "Asian American women" as both subjects and objects of study, while Grice largely centers "Asian American women" with little attention to how this category is formed through macro- and micro-processes of subject formation.

\section{Culture as Everyday Acts and Practices}

Other scholarly works that uphold culture as promising sites of resistance are grounded in ethnographic research that address everyday acts and practices as manifestations of citizenship for transnational Asian Americans. In "Biyuti in Everyday Life: Performance, Citizenship, and Survival among Filipinos in the United States," Martin Manalansan privileges the quotidian in processes of citizenship-making (2001). He draws from his ethnographic work in Filipino communities located in California and New York. The author considers significant the everyday tasks or performances involved in the daily survival of transmigrants, such as the dialogue and actions at the family dinner table between conflicting generations and cultural ideals. He presents three ethnographic vignettes as illustrative of how everyday performative acts can constitute the U.S. Filipino's struggle to survive when full assimilation is not a possibility (155-6). Such acts of survival include interactions during family dinners, Church groups, karaoke sing-alongs, praying, and other aspects of family life. These quotidian acts constitute the author's definition of citizenship: "Citizenship, as the quotidian performance of survival, then becomes the necessary weapon against the position of monolithic scripts of legal and cultural personhood and nationhood" (170). This form of citizenship differs from those discussed by the other scholarly works in this literature review. Even though Lowe and Grice both also address political activity and identity via culture, they approach culture as material productions 
such as testimonials, novels, and autobiographical narratives. Manalanan and Aihwa Ong (1996) also address political activity and identity via culture; however, they define culture as not material productions but as everyday acts of survival. Additionally, Ong examines everyday culture as both racialized and gendered acts of survival.

Though Manalansan does not label his notion of citizenship for U.S. Filipinos as "cultural citizenship" per se, Ong perhaps would. In "Cultural Citizenship as Subject-Making: Immigrants Negotiate Racial and Cultural Boundaries in the United States," she presents the concept of "cultural citizenship" as:

the cultural practices and beliefs produced out of negotiating the often ambivalent and contested relations with the state and its hegemonic forms that establish the criteria of belonging within a national population and territory. . becoming a citizen depends on how one is constituted as a subject who exercises or submits to power relations. (738)

There are striking similarities across these two authors' concepts of citizenship as contextualized within transnational capitalism. Drawing from ethnographic research, they both approach culture as including everyday practices-and not solely as cultural productions in the form of mass media, literature, or autobiographical narratives. They also similarly reject the space of social interaction as either one of "free agency" or "finite social destiny." Ong conceives of such space as constituted by the "dual process of self-making and being made within webs of power" (738). There are distinct differences, though, in what these two authors highlight as considerations in their concepts of cultural citizenship. While Manalansan focuses on "the quotidian performance[s] of survival" that are primarily located in civil society, Ong examines daily negotiations of citizenship with both civil society and the state.

She grounds her theorizations in ethnographic research aimed to investigate how "hierarchical schemes of racial and cultural difference intersect in a complex, contingent way to locate minorities of color from different class backgrounds" (737). She compares two groups of Asian immigrant communities in the U.S.: "poor" Cambodian refugees and "affluent" Chinese cosmopolitans, and she finds class and "location in the global economy" instrumental to the level of access non-white immigrants in the U.S. have to institutions (ibid). While Chinese cosmopolitans-transnationals with significant financial and real estate investments in the U.S. and abroad-have the global and local economic power to discipline state and civil institutions at times, they still largely face cultural rejection as legitimate members in the national body. In her readings of Cambodian refugee communities, she also suggests cultural 
citizenship as racialized, classed, and gendered processes. These refugee communities encounter the disciplining of the welfare state, the imposition of white middle-class masculinity and femininity by religious institutions, and the "feminist fervor of many social workers" in cases of domestic abuse (743-7). However, she shows how Cambodian refugee women on a daily basis negotiate these systems - institutions that simultaneously discipline them-to discipline their abusive spouses. For example, she cites a case in which an abused refugee woman called upon, and threatened to call upon, local enforcement and social service agencies to control her abusive husband's behavior. This is an act of agency and power in otherwise oppressive situations in the home and with the state. In this case, the author clearly illustrates her concept of cultural citizenship as "dual processes of self-making and being-made within webs of power linked to the nation-state and civil society" (738).

\section{“CULTURAL CITIZENSHIP” AS DEBILITATING}

Lowe, Manalansan, and Ong approach culture as alternative sites of citizenship-making. Lowe upholds culture as a promising site of resistance, and Manalansan and Ong theorize culture as everyday acts and practices of survival. For the latter two scholars, the promises of culture are less certain. "Quotidian struggles" of survival, that constitute meanings of citizenship for many transnationals, are fraught with multiple intended and unintended consequences that are not easily construed as acts of either resistance or oppression; they are mired in complicated "webs of power." David Leiwei Li (2000) and Helen Jun (2003), on the other hand, are less optimistic, as they approach culture as fully oppressive and symptomatic of the liberal myth of citizenship. They reject culture as productive sites of resistance in the struggle towards equal citizenship.

In the introduction "Alienation, Abjection, and Asian American Citizenship" to Imagining the Nation, Li studies contemporary Asian American literature to explore meanings of Asian American citizenship within the contemporary period of "Asian abjection" (2000). It is in conversation with Volpp's fourth form of identity as he situates his analysis of Asian American citizenship within "national imagery" or, in other words, the nation's dominant vision of itself. He introduces an Asian American genealogy of American Orientalism to frame formations of the "Asian American abject or unviable subject" (5). This genealogy is delineated by modes of production, forms of political culture, and figures of representation. He puts forth two periods: "Oriental alienation" spans from 1854-1943/1965; and "Asian abjection" spans from 1943/1965-present (ibid). During "Oriental alienation," monopoly capitalism reigned as the mode of production, the political culture was one of old orientalism (in the forms of nationalism and imperialism), and the figure of representa- 
tion was the Oriental (ibid). When late/transnational capitalism replaced monopoly capitalism, neo-orientalism - in the forms of neoconservatism and neocolonialism-replaced old orientalism, and the Oriental was replaced by the Asian American (ibid). The shift in representation from Oriental to Asian American is marked by a change in legal status. The "Oriental" was legally constructed through immigration and naturalization exclusions as an "othered" object of prohibition and "personified the historical tension between America's universalist promise of democratic consent and its race-, gender-, and culture-specific practice of citizenship" (5-6). Although "Asian Americans" abstractly became equal and full citizens, they certainly had not come to represent the nation's identity (6). The Asian American "abject" occupies a contradictory location where Asian Americans are legally included as citizens yet not seen as competent, politically and culturally, to be fully American. In other words, they are "formal nationals and cultural aliens" (12). Ngai similarly terms this contradictory location as "alien citizen[ship]" (170). Additionally, this is the same contention put forth by Volpp, Kang, Yamamoto et al., Lowe, Grice, Manalansan, and Ong, and missed by scholars such as Yang, Shanahan and Olzak, and Shah.

$\mathrm{Li}$, however, opposes Lowe's conceptualization of Asian American culture as a fruitful alternative site of resistance to hegemonic notions of citizenship. He repositions culture as a symptom of American citizenship and instead calls for a "radical divorce of racial inheritance and national competence" (15). This call to rupture race from cultural and political membership is also voiced by many other scholars referenced in this paper. Lowe posits culture as a site where work toward accomplishing this rupture can occur, while Li considers culture too embedded in the abjection of Asian Americans. He, however, does not offer an alternative maneuver.

Similar to Li, Helen Heran Jun argues that culture is part of the hegemony (2003). She poses identity as a discourse of citizenship where institutions of law, politics, economy, and culture collide to reveal how cultural productions fail to resolve the crises of racialized and gendered citizenships. Her dissertation, Race for Citizenship: Asian American and African American Cultural Politics, frames meanings of Asian American citizenship differently than other reviewed texts that focus only on intraracial and often intra-ethnic literatures. She demonstrates the interdependency of U.S. Black and Asian cultural institutions in their narrations of citizenship with a focus on the post-Reconstruction and World War II periods. Constructions of Asian American and African American citizenships are mutually constitutive, each arguing against and degrading the other to make claims of greater legitimacy in the national body via "citizenship narratives": 
Legal cases, court rulings, constitutional amendments, and congressional debates are constructed as key elements in historicizing the shifting boundaries of U.S. citizenship. However, making claims to citizenship has always entailed more than just waging legal contestations for political inclusion. Citizenship demands narratives from those who are excluded. Claiming citizenship demands the telling of stories, which can somehow employ historical processes of violence, dehumanization, brutality, and exploitation into a developmental universalizing narrative that resolves in the telos of an ethical subject 'worthy' of state recognition. (4-5; emphasis in original)

In other words, the "citizenship narratives" present in both Asian American and African American cultural productions operate to dehumanize and, consequently, construct the other as not "worthy of state recognition" and, thus, present itself as alternatively worthy of national membership. These citizenship narratives are racialized, gendered, and sexualized. If placed in conversation with Li's framework of the "abject," Jun examines the citizenship narratives of both the "Oriental" and "Asian American abject" and, similar to Li, views these cultural productions as not the solution to resisting hegemonic notions of citizenship but instead contributing to the marginalization of Asian Americans. Unlike Grice who centers Asian American women but largely neglects an analysis of gender, Jun examines citizenship as both raced and gendered processes. With respect to Volpp's four forms of citizenship, the author touches upon each of them; however, she elaborates on the citizenship discourse of identity by studying citizenship narratives. Culture fails to "resolve the gender, class, and racial violences that cannot be reconciled with formal political equality" (9). The author impressively demonstrates this through her comparative and gendered analyses of competing Asian American and African American narratives of citizenship.

\section{LANGUAGE, CULTURE, AND CITIZENSHIP}

Language is intimately tied to culture and identity. In conversations about citizenship and legitimate belongings to the U.S. national citizenry, an individual's language, when it matches the dominant language, is a form of linguistic capital - a type of cultural capital that provides access to power, knowledge, and success (Jo 2003-2004). The institution of education, specifically language education, is a site where national identity formations for Asian Americans are internally developed and/or externally assigned in order to (il)legitimize membership in the national body. In an assimilationist model, the English language is privileged and insti- 
tutionalized as the rightful language of the American citizenry. It is thought that English language acquisition is the key-with little attention to systems of racial, gender, and class oppressions - to assimilating minorities into the mainstream as American citizens. However, language as cultural capital is embodied differently for non-white immigrants precluding myths of seamless assimilation (Jo, 38). In addition, for transnational Asian immigrants, for whom English is not their first language, monolingual education obstructs learning and success in school (Jo, 37). The scholarly works on this topic focus on racialization and transnationalism; however, gendered aspects of this conversation are largely left unexamined by the existing scholarship.

In 'Educating 'Good' Citizens: Imagining Citizens of the New Millennium," Ji-Yeon Jo shows how citizenship has meanings beyond legal notions and how hegemonic citizenship, produced through systems of power including the education system, privileges the "rightful and good citizens" as English-speaking, white, and of European descent. Similarly, Morris Young in Minor Re/Visions: Asian American Literacy Narratives as a Rhetoric of Citizenship is also concerned with educational practices that construct a national identity that excludes Asian Americans (2004). He introduces the concept of "literacy narratives," or autobiographical citizenship narratives, as methodological and pedagogical tools for understanding how language education shapes national identity formations.

Jo contends that, for non-white immigrants, linguistic capital earned by English language acquisition is valued less than if embodied by white Americans and white immigrants. Language education plays a significant role in processes of belonging. It is a "medium of power" and demarcates boundaries between communities and nations, cultures, and ethnic groups (38). In support, Young provides an in-depth history of how Hawaii's English Standard schools reified structures of white economic, political, educational, and cultural imperialism over non-whites in Hawaii. In conversation with Volpp's and Grice's national identity and citizenship discourses, Jo argues that the current education system, based on the classic assimilationist model and mono-lingualism, desires the formation of an Anglo-citizenry as the American national identity. Jo and Young argue that current curricula emphasizing English-only language education do not support the needs and circumstances of Asian Americans and transnational immigrants who inhabit multiple cultural identities and languages.

Both authors examine the implications of hegemonic notions of citizenship for Asian American adolescents in the education system, with an emphasis on English-only language education, within a context of racialization, transnational migration, and globalization. Jo argues that the classic assimilation model is not appropriate for the experiences of Asian 
Americans and transnational immigrants, and Young contends that dominant culture has demanded marginalized subjects demonstrate legitimacy as citizens or future citizens through literacy and education. However, this sought-after legitimacy has never fully been granted. According to these authors, naturalized citizenship and linguistic competency do not transform Asian immigrants into legitimate "Americans" as they remain marginalized due to racism. As posed by Li and Ngai, this exemplifies the contradictory location of "abjection" and "alien citizen[ship]." Jo asks the following question which resonates with Mansfield-Richardson's attempts to operationalize "Asian American":

for many non-white immigrants, legal citizenship and U.S. born status do not make much difference in their day-to-day lives. Many non-white legal citizens of the United States report they feel alienated and are treated as 'foreigner' or 'other' by fellow citizens despite their long residence or native-born status in the United States. Then what makes one a 'true' citizen of the United States? (Jo 36)

Assimilationist thought assumes acquisition of the dominant language, customs, and cultural values as the key processes through which immigrants become Americans (34). However, the author contends that English language education is actually the main source of educational issues for immigrants. Based on ideas of assimilation, it is thought that immigrant adolescents ought to supplant their "native" language with English; however, studies show that bilingual Southeast Asian American adolescents fare more successfully in school compared to their monolingual English-speaking counterparts (37). Young proposes modifications to existing curricula, including sample class lessons and syllabi, and "literacy narratives" as pedagogical tools to help students critically reflect on the role of literacy in normalizing American national identity. He considers literacy narratives tools of curriculum transformation that bring light to the role language education and literacy play in citizenship-making processes for Asian Americans. In other words, curricula based upon the classic assimilationist model are inappropriate linguistically and culturally for transnational immigrant adolescents (ibid). Acquisition of linguistic capital — a form of cultural capital — when racially embodied as "Asian," insufficiently provides access to the national identity and legitimate citizenry. The current education system functions to exclude those deemed culturally, linguistically, racially, and socio-economically undesirable from enjoying full acceptance into the American national identity. 


\section{CONCLUSION AND NOTES FOR FURTHER RESEARCH}

Are there forms of citizenship, other than legal status and rights, to explain the experiences and histories of Asian American men and women, as well as provide anti-racist, feminist sites of resistance in the struggle for equality? In working through this question, four patterns emerge in the analysis of racialized and gendered citizenship discourses with respect to Asian American women and men. First, many scholarly inquiries do not complicate meanings of citizenship beyond legal status or the universal male referent. Second, examinations in critical race studies and immigration history confront assumptions of citizenship as legal status and rights through a lens of racialization. Third, works on citizenship that either center women and/or engender its subjects examine culture as a space of identity formation and political activity and analyze both race and gender. Culture, as either a productive or debilitating site of resistance for Asian American women and men, is also contested. The final theme addresses language education as a realm of citizenship and national identity formations with racialized, but not explicitly gendered, implications.

Meanings of citizenship beyond liberal notions of legal status and rights, such as political activity and identity, are additional forms of citizenship that are largely theorized in cultural analyses. In terms of identity, Asian Americans are largely seen as culturally inadequate and ineligible to represent the national body. Institutions and culture-such as mass media, press, literature, autobiographical and literacy narratives, "quotidian" and everyday processes of "self-making and being made"are already examined sites in which citizenship-making occurs historically and presently. Further research could extend culture to include public health discourses as sites for racialized, gendered, and sexualized discourses of citizenship. Inquiries could include: How do cultural representations and institutional practices during public health anxieties affect the four forms of citizenship for Asian American women and men? Can these subjects utilize culture as an alternative site of resistance against racist, sexist, nativist, classist, and heterosexist public health discourses? Perhaps, exploring these lines of inquiry could shed light on the processes by which Asian Americans have been framed historically as medical scapegoats-such as during the bubonic plague outbreaks in San Francisco at the turn of the twentieth century and the more recent casethe SARS outbreak of 2003. 


\section{REFERENCES}

Asian Women United of California, ed. Making Waves: An Anthology of Writings By and About Asian American Women. Boston: Beacon Press, 1989.

Grice, Helena. Negotiating Identities: An Introduction to Asian American Women's Writing. Manchester and New York: Manchester University Press, 2002.

Jo, Ji-Yeon O. "Educating 'Good' Citizens: Imagining Citizens of the New Millennium." The High School Journal 87, no. 2 (2003-2004): 34-43.

Jun, Helen Heran. Race for Citizenship: Asian American and African American Cultural Politics. Dissertation. San Diego, CA: University of California, San Diego, 2003.

Li, David Leiwei. Imagining the Nation: Asian American. Stanford, CA: Stanford University Press, 2000.

Lowe, Lisa. Immigrant Acts: On Asian American Cultural Politics. Durham, NC: Duke University Press, 1996.

Kang, Laura. Compositional Subjects: Configuring Asian/American Women. Durham, NC: Duke University Press, 2002.

Manalansan IV, Martin F. "Biyuti in Everyday Life: Performance, Citizenship, and Survival among Filipinos in the United States." In Orientations: Mapping Studies in the Asian Diaspora, eds. Kandice Chuh and Karen Shimakawa. Durham, NC: Duke University Press, 2001.

Mansfield-Richardson, Virginia. Asian Americans and The Mass Media: A Content Analysis of Twenty United States Newspapers and A Survey of Asian American Journalists. New York: Garland Publishing, 2000.

Ngai, Mae. Impossible Subjects: Illegal Aliens and the Making of Modern America. Princeton, NJ: Princeton University Press, 2004.

Okihiro, Gary. The Columbia Guide to Asian American History. New York: Columbia University Press, 2001.

Olzak, Susan and Suzanne Shanahan. "Racial Policy and Racial Conflict in the Urban United States, 1869-1924." Social Forces 82, no. 2 (2003): 481-517.

Omi, Michael and Howard Winant. Racial Formation in the U.S. from the 1960s to the 1990s. New York: Routledge, 1994.

Ong, Aihwa. "Cultural Citizenship as Subject Making: Immigrants Negotiate Racial and Cultural Boundaries in the United States." In 
Race, Identity, and Citizenship: A Reader, eds. Rodolfo D. Torres, Louis F. Miron, and Jonathan Xavier Inda, 262-293. Malden, MA: Blackwell Publisher, 1999.

Shah, Hemant. "Race, Nation, and Citizenship: Asian Indians and the Idea of Whiteness in the U.S. Press, 1906-1923." The Howard Journal of Communications 10, no. 4 (1999): 249-267.

Thomas, Brook. "China Men, United States v. Wong Kim Ark, and the Question of Citizenship." American Quarterly 50, no. 4 (1998): 689-717.

Volpp, Leti. “ 'Obnoxious To Their Very Nature': Asian Americans and Constitutional Citizenship." Citizenship Studies 5, no. 1 (2001): 5772. United States Citizenship and Immigration Services. "Citizenship." 13 September 2004. <http://uscis.gov/graphics/services/natz/ citizen.htm> 8 December 2004. United States Citizenship and Immigration Services. "This Month in Immigration History: March 1790." 6 Dec 2004. <http://uscis.gov/graphics/aboutus/history/ mar1790.htm> 8 December 2004. United States House of Representatives. "Amendments to the Constitution." 20 September 2004. $<$ http://www.house.gov/Constitution/Amend.html> 8 December 2004.

Yamamoto, Eric K., Margaret Chon, Carol Izumi, Jerry Kang, and Frank Wu. Race, Rights and Reparation: Law and The Japanese American Internment. New York: Aspen Law \& Business, 2001.

Yang, Philip Q. "Sojourners or Settlers: Post-1965 Chinese Immigrants." Journal of Asian American Studies 2, no. 1(1999): 61-91.

Young, Morris. Minor Re/Visions: Asian American Literacy Narratives as a Rhetoric of Citizenship. Carbondale: Southern Illinois University Press, 2004. 